\begin{tabular}{c} 
Volume and Issues Obtainable at Center for Sustainability Research and Consultancy \\
Journal of Business and Social Review in Emerging Economies \\
ISSN: 2519-089X (E): 2519-0326 \\
Volume 5: No. 1, June 2019 \\
CSRᄃ \\
Journal homepage: www.publishing.globalcsrc.org/jbsee \\
\hline
\end{tabular}

\title{
Factors influencing the investor's decision in Syrian Initial Public Offering Market: survey Study
}

\author{
${ }^{1}$ Musaab Mousa, ${ }^{2}$ Sagi Judit, ${ }^{3}$ Zeman Zoltan \\ ${ }^{1}$ Ph.D Scholar, school of business and management sciences, Szent István University, Hungary, \\ mosaabmosa@gmail.com \\ ${ }^{2}$ Lecturer, Department of finance, Budapest Business School, sagi.judit@uni-bge.hu \\ ${ }^{3}$ Lecturer, Faculty of Economics and Social Sciences, Szent István University, Hungary, \\ zeman.zoltan@gtk.szie.hu
}

\begin{tabular}{l} 
ARTICLE DETAILS \\
\hline History \\
Revised format: November 2019 \\
Available Online:December 2019
\end{tabular}

Keywords

Initial Public Offering IPO,

Timing, Owners' Reputation,

Marketing Efforts Syria

JEL Classification:

R53, R59

\begin{abstract}
Purpose: The purpose of this paper is to investigate the role of company industry, IPO timing, owners' reputation and marketing efforts in investor's decision in Syrian initial public offering market IPOs

Design/Methodology/Approach: A questionnaire survey was administered to 270 investors in Damascus Securities Exchange. Some descriptive statistics and One-Sample tests were used to analyze the data and test the hypotheses.

Findings: The research found that investor's decision is influenced significantly by IPO timing, owner's reputation and marketing efforts in the Syrian IPOs market.

Implications/Originality/Value: This research presents that Syrian companies can use these factors as an approach to increase the quality of their IPO, on another hand, financial regulators can enhance the IPO control process, adding to the results that can contribute to understanding marketing-finance interface and behavioral finance literature.
\end{abstract}

(C) 2019 The authors, under a Creative Commons Attribution-

NonCommercial 4.0

Corresponding author's email address: mosaabmosa@gmail.com

Recommended citation: Mousa, M., Sagi, J and Zeman, Z. (2019). Factors influencing the investor's decision in Syrian Initial Public Offering Market: survey Study. Journal of Business and Social Review in Emerging Economies, 5 (2), 287-294

DOI: $10.26710 /$ jbsee.v5i2.814

\section{Introduction}

As an important part of the financial system, financial markets have become an important pillar of the modern economy. It provides good opportunities for individual investors as well as funding for private and government institutions. It also provides a convergence of borrowers with lenders and thus contributes to the efficiency of the economy through the efficient allocation of capital, which includes an economic function in the welfare of society. Conversely, market vibrations or poor regulation are leading to serious economic consequences. (Mishkin, 2004)

The capital market is a marketplace in which financial insturments are issued and traded (Jakob.et al, 2009, p65). In other words, it is the framework in which the supply and demand sides of securities interact regardless of the spatial dimension (Gitman \& Joehnk, 2008), and are mainly divided into primary markets where securities are sold for the first time, and the secondary market is concerned with post-issue transactions ( (DG EAC, 2010) Thus, institutions 
obtain long-term financing in the primary market through the IPO process, which involves creating new securities when the company is established or when its shares are put on the public market and Her money after listing in the secondary market. (Ross et al, 2008)

IPO plays an effectual economic role, as one of the channels of investment flow across markets. According to the World Federation of Exchanges (WFE), the total value of newly created shares in 2016 was around US \$142.5 billion and the total value of the capital increase of listed companies was US \$ 672.3 billion. While the total value of bonds issued was approximately US \$ 4.327 trillion, 1,349 companies issued new shares during the year (World Economic Forum, 2016). However, IPO offers many benefits to the issuing company, such as increased funding for the expansion of activities and markets as well as the IPO helps in increasing the company's recognition and position in the financial community, which can reduce the cost of capital.

On the other hand, many kinds of literature tried to explain the investor's decision in capital market because of his significant place within the market through economic utility theory perspective depending on four assumptions: (1) completely rational, (2) able to deal with complex choices, (3) risk-averse and (4) wealth-maximizing, where investor prefers opportunity maximize expected return and minimize risk (Nagy\&Obenberger, 1994). Likewise, subsequent studies depend on "bounded rationality" term showed that investors are prone to biases, which led to the development of behavioral finance theories (Ndirangu. et al, 2015)

Furthermore, the affected factors on investor's decisions have paid much attention to finance studies in the primary market. Bell.et al (2014) examined the role of governance mechanisms on investors' valuation of foreign IPO's in the USA, they found relationship between governance and investors' appetite for IPO's. Bruton.et al (2010) argued that concentrated ownership improves IPOs' performance in English and French companies went public.wang.et al (2017) showed that herd behavior influences IPO's demand in Taiwan market. In addition to the literature that studied differences in personal factors among investors such as Ndirangu. et al (2015) who pointed to the differences in investment decisions in the Kenyan market as a result of demographic characteristics between men, women, youth and the elderly, in addition to the social situation with regard to the preferences of the poor and rich. Furthermore, much previous research has examined the variables affected on investor 'decision in secondary market during exchange such as Kadariya (2012) investigated the impact of information on investor 'decision in Nepales stocks exchange, the findings showed that capital structure, political and media coverage, the financial education and trend analysis have impact on investor decision. Islamoğlu et al (2015) by using factor analysis methodology, determined the factors affected on investor behavior in Turkish markets.

In the same context, this paper attempts to determine the role of some proposed factors in investor's decisions during IPO's sin the Syrian market in the Medial East region. According to the literature review, four variables had determined, they classified as objective rather than personal factors by using survey methodology considering behavioral finance view.

The remainder of the paper is structured as follows. The background of the Syrian IPOs market is presented in Section 2. Section3 presents a theoretical discussing of the IPO process as well as a proposed factor with hypotheses development, section 4 presents data and methods adopted in the empirical study. Section 5 presents results and discussion of hypotheses. Section 6 presents the conclusion of the paper and future recommendations.

\section{Syrian IPO's Market}

The Syrian IPO market witnessed significant developments after 2000, especially with regard to the regulatory framework of the market with the establishment of the Syrian Commission for Financial Markets and Securities (SCFMS) as a regulator of the financial markets and the activities attached thereto in The number of Syrian companies that issued new shares during the period (2003-2009) is 21 , knowing that the IPO was completely stopped after 2011 due to the security and political crisis. The total value of IPOs in the period under study is the US $\$ 342$ million, equivalent to $35 \%$ of the total capital, as well as the coverage or increase of the IPO between $100 \%$ and $988 \%$ as in Table 1 :

Table (1) IPO’s in Syria (2003-2009) 


\begin{tabular}{|c|c|c|c|c|c|}
\hline Company & year & amount SP & amount USD & $\begin{array}{l}\text { IPO } \\
\text { percentage of } \\
\text { capital }\end{array}$ & $\begin{array}{l}\text { Coverage } \\
\text { ratio }\end{array}$ \\
\hline Banque Bemo Saudi Fransi & 2003 & $857,000,000$ & $17,140,000$ & $49 \%$ & $102 \%$ \\
\hline $\begin{array}{l}\text { The International Bank for } \\
\text { finance \& Trade }\end{array}$ & 2003 & $702,600,000$ & $14,052,000$ & $47 \%$ & $111 \%$ \\
\hline $\begin{array}{l}\text { Bank of Syria and } \\
\text { Overseas }\end{array}$ & 2003 & $1,189,500,000$ & $23,790,000$ & $40 \%$ & $208 \%$ \\
\hline Bank Audi & 2005 & $625,000,000$ & $12,500,000$ & $25 \%$ & $988 \%$ \\
\hline Arab Bank & 2005 & $364,950,000$ & $7,299,000$ & $24 \%$ & $441 \%$ \\
\hline Byblos Bank Syria & 2005 & $300,000,000$ & $6,000,000$ & $15 \%$ & $198 \%$ \\
\hline Syria Gulf Bank & 2006 & $390,000,000$ & $7,800,000$ & $26 \%$ & $245 \%$ \\
\hline Cham Bank Islamic & 2006 & $1,250,000,000$ & $25,000,000$ & $25 \%$ & $518 \%$ \\
\hline $\begin{array}{l}\text { United } \\
\text { Company }\end{array}$ & 2006 & $433,500,000$ & $8,670,000$ & $51 \%$ & $107 \%$ \\
\hline $\begin{array}{l}\text { Syrian Kuwaiti Insurance } \\
\text { Company }\end{array}$ & 2006 & $425,850,000$ & $8,517,000$ & $50.1 \%$ & $167 \%$ \\
\hline $\begin{array}{l}\text { National } \quad \text { Insurance } \\
\text { Company }\end{array}$ & 2006 & $450,500,000$ & $9,010,000$ & $53 \%$ & $100 \%$ \\
\hline $\begin{array}{l}\text { SyriaInternational } \\
\text { Insurance- Arope }\end{array}$ & 2006 & $503,000,000$ & $10,060,000$ & $50 \%$ & $100 \%$ \\
\hline Orient Insurance Company & 2006 & $433,500,000$ & $8,670,000$ & $51 \%$ & $100 \%$ \\
\hline $\begin{array}{l}\text { Syria International Islamic } \\
\text { Bank }\end{array}$ & 2007 & $2,550,000,000$ & $51,000,000$ & $51 \%$ & $336 \%$ \\
\hline $\begin{array}{l}\text { Al-Aqeelah } \\
\text { Insurance }\end{array}$ & 2007 & $1,020,000,000$ & $20,400,000$ & $51 \%$ & $101 \%$ \\
\hline $\begin{array}{l}\text { SolidarityAlliance } \\
\text { Insurance }\end{array}$ & 2007 & $510,000,000$ & $10,200,000$ & $51 \%$ & $144 \%$ \\
\hline Bank Of Jordan- Syria & 2008 & $505,200,000$ & $10,104,000$ & $34 \%$ & $100 \%$ \\
\hline Fransabank- Syria & 2008 & $630,000,000$ & $12,600,000$ & $36 \%$ & $235 \%$ \\
\hline
\end{tabular}




\begin{tabular}{|l|l|l|l|l|l|} 
Bank Alsharq & 2008 & $\mathbf{5 1 2 , 5 0 0 , 0 0 0}$ & $10,250,000$ & $21 \%$ & $438 \%$ \\
\hline Qatar National Bank & 2009 & $\mathbf{1 , 7 0 0 , 0 0 0 , 0 0 0}$ & $34,000,000$ & $34 \%$ & $268 \%$ \\
\hline Al Baraka Bank & 2009 & $\mathbf{1 , 7 5 0 , 0 0 0 , 0 0 0}$ & $35,000,000$ & $35 \%$ & $428 \%$ \\
\hline
\end{tabular}

Sours: www.scfms.sy

\section{Theoretical Discussing}

\subsection{IPO process}

The IPO process encompasses several phases. First, when an issuer decides to issue new shares, it contracts with a lead manager or underwriter. In general, investment banks are responsible for this task, except when the task is assigned to brokerage firms in some cases. A syndicate of a leading investment bank and several other banks is usually formed to manage the issuance process (Basdeo et al, 2006)

The second step involves the legal arrangements of the regulator (the Securities Market Authority) that regulates and oversees the IPO market. The company must submit a set of documents attached to the issuance application in preparation for acceptance of the prospectus by SCA (SCFMS, 2006). The prospectus is a brochure containing a detailed information package for the issues such as the use of the proceeds of the issuance, management team information and economic feasibility with a view to protecting investors and providing all possible information necessary for their decisions (Arkebauer \& Schultz, 1999).

The final stage of the IPO is when new shares become publicly available in the market and investors who wish to subscribe to the quantities they want during the announced period begin the allocation process, ending with the announcement of the success of the IPO "tombstone."

\subsection{Proposed Factors and Hypotheses Development}

Four factors have been suggested considering the literature review to study their effect on investor's decision during IPO's: company industry, Timing of IPO, the reputation of funders and marketing efforts during IPO.

\subsubsection{The Industry of the Company}

Generally, a lot of researchers studied the IPO in specific sectors such as Kalova (2017) in shipping sector, Satta.et al (2017) in port industry, Alqahtani\&Boulanouar (2017) in sharia compliance status, Anderloni \& Tanda(2017) in green energy companies, Initially, it is expected that investor preferences and therefore decisions will vary depending on the sector of the company issuing securities by IPO,IPO's are distributed between banks and insurance during the period under study in Syria Therefore, in this research so it is hypothesized that:

Hypothesis 1: company industry effect on investor's decision in the Syrian IPO's market.

\subsubsection{Timing of IPO}

Timing of going public is the most critical element in the IPO process, it is related directly to the success of IPO, and one-third of companies are convinced that timing of IPO is the most important point when considering an IPO (Deloitte, 2016). according to Ljungqvist (2006) during certain periods, individual investors are very optimistic and overvalued the company shares, that motivate owners to take the decision of IPO,Similarly, the increase in demand more than supply during selling a new shears leads to "hot IPO" phenomenon as a result to some investment opportunities available to companies in particular period.(Benninga et al,2005), In short, the timing of IPO associated with investors' mode in one hand and company position in the other. Therefore, the second hypothesis in this paper as following:

Hypothesis 2: timing of IPO effect on investor's decision in the Syrian IPO market.

\subsubsection{The Reputation of the Involved Parties}

There is no specific and clear definition of company's reputation concept, where the definition was addressed according to different views of the researchers based on their scientific backgrounds, supposedly, the oldest definition of reputation has been contained in Webster's Dictionary in 1913 as "the assessment of public opinion to someone; the character to attribute to a person, thing or action; repute" (Manto \& Alan, 2001) 
In IPO's Market, reputation plays an important role for several Parties, first the reputation of issue manager (underwriter) has impact on demand for new shares and their price in secondary market letter, in the same time the underwriter has a direct interest in the success of IPO and getting good prices because the reverse may expose it to reputation risk, In contrast, the investment bank also prefers to deal with reputable companies regarding management and marketing of its issuances, which increases the chances of the bank to gain new issuers in the future, which is the same on the companies side as the contract with a reputable investment bank directly affects the outcome of the IPO. (Nanda,1997),(Guner et al,2000), (Ertuna et al, 2003), (Kenourgios et al, 2007) and(Yip et al,2009),

With respect to founders and block holder's reputation, some studies concluded that reputation of venture capitalist firms contributes directly to success of IPO and its performance after issuing (Krishnan et. al, 2011), As well for large owners who enhance the performance of shares in the market after listing because of their reputation especially, when they keep their investments in the corporation. (Cronqvist \& Fahlenbrach, 2009) Consequently, the third hypothesis in this paper as following:

Hypothesis 3: owner's reputation effect on investor's decision in the Syrian IPO market.

\subsubsection{Marketing Efforts During IPO}

According to Luo (2008), most of the IPO research has been studied in the financial literature, while it has not received sufficient attention from a marketing perspective. Therefore, the "marketing and finance interface" is an effective approach to creating value for shareholders, and has concluded that there is a relationship between marketing spending received from the IPO depending on customer equity theory of market-based assets,

Bahadir et al (2015) focused on signal theory as a theoretical framework for the relationship between the company's ability to attract potential investors to its issues and its marketing efforts before issuance, where marketing efforts provide a clear signal to investors about the quality of the company and its future.

On the other hand, Demers and Willen (2002) found that media attention leads to an increase in the IPO price in the stock market as well as improved product market performance for Internet companies in the USA. In addition, Cook et al (2006) proved the important role of advertising in attracting new investors and achieving issuance goals. Based on the above, this research is hypothesized that:

Hypothesis4: marketing efforts during IPO effect on investor's decision in the Syrian IPO market.

\section{Data and Methods}

In order to achieve the objectives of the research in defining the impact of the company's industry, the timing of the IPO, the reputation of the owners and the marketing efforts on the investors' response for the IPO, the preliminary data was approved through the questionnaire form for individual investors in the Damascus Securities Exchange. A total of 270 analyzable forms were retrieved $(\mathrm{N}=270)$

The questionnaire involves two parts, the first part about for personal information of the respondents, and the second for questions of four proposed factors divided into 20 questions depending on the Fifth Likert Scale. Also, the validity and reliability of the questionnaire were tested using Alpha Cronbach test, where the results refer to the validity of every question and the questionnaire as a whole $(>0.8)$.

Statistical Package for Social Science (SPSS) Version 20 software by IBM is used to data analysis and to infer the relationship between the variables. We used some descriptive statistics and a one-sample t-test to testing research hypotheses by definition which factor has the most and least impact on investors' decisions in the Syrian IPOs market.

\section{Results and Discussion}

In this part, the analysis of collected data was conducted regarding the characteristics of the sample and descriptive statistics of variables in addition to hypotheses testing.

\subsection{Sample Criteria Analysis}

The characteristics of the studied sample are shown in table 3-1 as follows: 
Most respondents $(61 \%)$ were male versus 39 percent are female. Based on age, about $75 \%$ of respondents are in the age group of 25- 35 followed by 12 percent in the 35-45 age group, while 10 percent are above 45 years. This indicates the nature of Syrian society where the majority of the population is young, which extends to investors of the financial market belonging to the same category.

In terms of educational background, 50 percent of respondents have a bachelor's degree and 37 percent have a master's degree. Regarding investment experience. Majority of the respondents $(56 \%)$ have 6-10 years of investment experience, while $28 \%$ have 1-5 years of experience. It is a result of the fact that the stock market in Syria is a new one that was opened in 2009 and thus the experience of investors in this sector.

Regarding occupation, 59 percent of the respondent belonge to freelancers group, while 31 percent are from employees' group. On the other hand mor than half of sampl ( 51\%) had a bachelor's degree, 37 percent had master degree.

Table 3.1 Criteria of Respondents' Sample

\begin{tabular}{|c|c|c|c|c|c|}
\hline Gender & Male & Female & & & $\mathrm{N}$ \\
\hline Percentage & $61 \%$ & $39 \%$ & & & \multirow{9}{*}{270} \\
\hline Age & Less than 25 & $25-35$ & $35-45$ & More than 45 & \\
\hline Percentage & $3 \%$ & $75 \%$ & $12 \%$ & $10 \%$ & \\
\hline occupation & employee & freelancers & student & retirees & \\
\hline Percentage & $31 \%$ & $59 \%$ & $6 \%$ & $4 \%$ & \\
\hline Education & High school & bachelor's & Master & $\mathrm{PhD}$ & \\
\hline Percentage & $13 \%$ & $50 \%$ & $32 \%$ & $5 \%$ & \\
\hline Experience & $1-5$ years & $6-10$ years & $11-15$ years & $\begin{array}{l}\text { More than } 15 \\
\text { years }\end{array}$ & \\
\hline Percentage & $29 \%$ & $59 \%$ & $10 \%$ & $2 \%$ & \\
\hline
\end{tabular}

Source: SPSS results

\subsection{Descriptive Statistics}

Table 3.2 contains the standard deviation and mean of the study variables to determine the significance of these variables statistically

Table 3.2 Descriptive Statistics

\begin{tabular}{|l|l|l|l|l|}
\hline Variable & $\mathrm{N}$ & mean & $\begin{array}{l}\text { standard } \\
\text { deviation }\end{array}$ & important \\
\hline Industry of company & 270 & 3.7111 & .91485 & High \\
\hline Timing of IPO & 270 & 4.2222 & .46875 & High \\
\hline Reputation of owners & 270 & 4.1000 & .70392 & High \\
\hline Marketing efforts & 270 & 3.5333 & 1.01727 & High \\
\hline
\end{tabular}

Source: SPSS results

All variables have high important means $(\geq 3.5)$, also the values of the means lay between 3.2 and 4.2 which refers to converging in terms of importance and indicates the similarities of the views of the sample on the variables influence. At the same time, standard deviation values indicate that respondents' answers are not dispersed.

\subsection{Hypotheses Test}

A single sample t-test was used to verify the research hypotheses in determining the impact of the four proposed factors on the investor's decision during the IPO,

Depending on the comparison of the calculated average with the adjusted average (3.4). An alternative hypothesis is accepted if the Sig level is smaller than the 5\% value. 
Table 3.3 the one-sample t-test results

\begin{tabular}{|l|l|l|l|l|}
\hline Variable & $\mathrm{t}$ & $\mathrm{df}$ & Sig. (2-tailed) & Hypothesis test \\
\hline Industry of company & 57.625 & 16 & .421 & rejection \\
\hline Timing of IPO & 2.582 & 16 & .020 & Acceptance \\
\hline Reputation of owners & 2.606 & 16 & .000 & Acceptance \\
\hline Marketing efforts & 4.123 & 16 & .010 & Acceptance \\
\hline
\end{tabular}

Source: SPSS results

The table shows that the significance level for all factors at $\mathrm{p}<0.05$ except "industry of company" factor, that means the sample agree with three hypotheses of research, and their investment decisions during IPO affected by timing of IPO, reputation of owners and marketing efforts, as well, investors negligence of to the company industry may be due to the weak of investment culture and the inability to distinguish the risks and benefits associated with each industry.

Investors do not attach importance to the sector of the company because of the structure of the IPO market, where financial companies dominated the size and number of issues during the period under study. Moreover, timing plays an important role in investor decision as a result of the published news and information impact in general, especially the news of the imminent opening of the Damascus Securities Exchange as a new channel for investment and to evaluate investments in the IPO, especially after taking into account the phenomenon of underpricing. Likewise, trust comes from reputations, especially when investing in companies that offer their shares for the first time to the public. It is also a reflection of society and culture that relies heavily on personal relationships, which spill over into business. At the same time, marketing efforts can change the outcome of the issuance with its overlaps to influence consumer/investor decisions, meaning that marketing before and in conjunction with the issuance helps the company achieve its goals by contributing to persuading potential investors.

\section{Conclusion}

The results of this paper show that three factors (Timing, reputation, and marketing) have a significant impact on an investor's demand at a new share issued by the IPO process. In other words, Syrian investors are paying more attention to these three variable, while not caring for the industry of firm issued new shares.

We hope that Syrian investors can enhance their knowledge and skills to make a fit investment decision decisions. Likiwiss, Syrian companies can also use this scintafic approach to increase the effeciency of the IPO decision, as well as capital market regulators that can empower IPO process monitoring.

Generaly, this study recommends that the Syrian policymakers should put a sold plan to encourage companies to go public, which may lead to economic advantages and diversification of investment channels, thus contributing to development goals atchevment.

For future research, more research for more factors that may influence investor decision in the financial market whether rational or behavioral, as well as a comparative study on the decisions of investors in different markets.

\section{References}

Alqahtani.F and Boulanouar.Z (2017) Sharia compliance status \& investor demand for IPOs: Evidence from Saudi Arabia, Pacific-Basin Finance Journal http://dx.doi.org/10.1016/j.pacfin.2017.09.012

Basdeo, D. K., Smith, K. G., Grimm, C.M., Rindova, V. P., \& Derfus, P. J. (2006). The impact of market actions on firm reputation. Strategic Management Journal, 27, 1205-1219.

Bell.R.G, I. Filatotchev and Aguilera.R.T.(2014) Corporate Governance and Investors' perception of foriegn IPO value : an institutional perspective, Academy of Management Journal, Vol. 57, No. 1, PP. 301-320.

Benninga.S, Helmentel.M,Sarig.O(2005). The timing of initial public offerings, Journal of Financial Economics 75, pp. 115-132.

Bruton.G.D, I. Filatotchev, Chahine.S and Wright.M (2009) Governance, ownership structure, and performance of IPO firms: the impact of different types of private equity investors and institutional environments, Strategic Management Journal, j.31, pp 491-509. 
Cook, O., Kieschnick,R., \& Van Ness,R.(2006). On the marketing of IPOs,Journal of Financial Economics 82 (2006) 35-61.

Commission on Financial markets and securities. (2006). Issuance regulation, No 3945, retrieved from http:// www.scfms.sy.

Cronqvist, H. and Fahlenbrach, R., 2009. Large shareholders and corporate policies, The Review of Financial Studies 22/10, 3941-3976.

Deloitte Development LLC. (2016). Private company IPOs: Is timing everything? Available at: https://www2.deloitte.com

Ertun., B., Ercan, M., \& Akgiray, V. (2003). The Effect of the Issuer-Underwriter Relationship on IPOs: The Case of an Emerging Market, Journal of Entrepreneurial Finance and Business Ventures: 3(8), 43-55. http://digitalcommons.pepperdine.edu/jef/vol8/iss3/4

Ginger N., Onder. Z., \& Rhodes, S.Z. (2000). Underwriter Reputation and Short-run IPO Retuims: A Re-evaluation for an Emerging Market, ISE Finance Award Series, 1, 85-112.

Gitman, L., \& Joehnk,M.(2008). Fundamentals of investing, 10th edition, Pearson Education, Boston.

Islamoğlu, M., Apan,M., Ayvali,A.(2015). Determination of Factors Affecting Individual Investor Behaviours: A Study on Bankers, International Journal of Economics and Financial Issues,5(2), 531-543

Georgios, D. F., Papathanasiou, S., \& Melas, E. R. (2007). Initial performance of Greek IPOs, underwriter's reputation, and oversubscription. Managerial Finance, 33(5), 332-343.

Klova, V.(2017).IPO underpricing: What about the shipping sector? J. Multinatl. Financial Management, http://dx.doi.org/10.1016/j.mulfin.2017.08.001

Krishnan, C. N. V., and Ivanov, V. I. and Masulis, R. W. and Singh, A. K., 2011. Venture capital reputation, postIPO performance and corporate governance, Journal of Financial and Quantitative Analysis 46/5, 12951333

L. Anderloni, A. Tanda (2017) green energy companies: Stock performance and IPO returns, Research in International Business and Finance 39 pp. 546-552.

Ljungqvist, A., Nanda, V., Singh, R. (2006). Hot markets, investor sentiment, and IPO pricing, the Journal of Business, 79, 1667-1703.

Manto .G, Alan M. W (2001). Corporate reputation: seeking a definition, Corporate Communications, An International Journal, Vol 6. N 1.pp. 24-30

Mishkin, F. S. (2006).The Next Great Globalization, Princeton University Press, Princeton.

Nagy.R.A and Obenberge.R.W (1994) Factors Influencing Individual Investor Behavior Financial Analysts Journal, pp63-68

Nanda, V. (1997). Reputation and Financial Intermediation: An Empirical Investigation of the Impact of IPO Mispricing on Underwriter Market Value. JOURNAL OF FINANCIAL INTERMEDIATION, 39-63.

Ndirangu, A.W, Ouma.B.O, and Munyaka.F.G (2015). factors influencing Individual Investor Behaviour during Initial Public Offers (IPOs) in Kenya, Research Journal of Finance and Accounting Vol.6, No.20, pp 2230.

Rose, P.,\& Marquis, M.(2008).Money and Capital Markets, McGraw-Hill, New York.

Satta. G, Notteboom.T, Parol. F and Persico.L (2017). Determinants of the long-term performance of initial public offerings (IPOs) in the port industry, Transportation Research Part A 103, pp 135-153.

Sudarshan, Kadariya. (2012). Factors affecting investor decision making: A case of Nepalese capital market, Journal of Research in Economics and International Finance,1(1), 16-30.

The Directorate-General for Education and Culture (DG EAC). (2010). financial markets, lifelong learning program, Transfer of Innovation, Latvia, Lithuania, and Bulgaria, http://ec.europa.eu/dgs/education_culture/index_en.htm

Wang.C.S,Tang.H.W and Chen.R.C.Y (2017). Does IPO subscription demand affect investor herd behavior in Taiwan?, International Review of Economics and Finance, 51, PP 252-272.

World Federation of Exchanges WFE.(2016). www.wfe.com

Yip, Y., Su, Y., and Ang, J. B. (2009). Effects of underwriters, venture capital and industry on long-term initial public offering performance. Managerial Finance, 35(8), 700-715 